\title{
CONSTRUÇÕES PERSUASIVAS DE ORADORES EM LIVES DURANTE A PANDEMIA
}

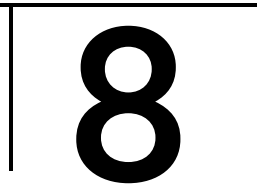

\section{PERSUASIVE CONSTRUCTIONS OF ORATORS IN LIVES STREAMS DURING THE PANDEMIC}

\author{
SANTOS, Maria Francisca Oliveira \\ Doutora em Letras pela Universidade Federal da Bahia e pós-doutorado na mesma área pela \\ Universidade Federal da Bahia. \\ Docente da Universidade Federal de Alagoas e da Universidade Estadual de Alagoas \\ E-mail: mfosal@gmail.com \\ ORCID ID: https://orcid.org/0000-0002-0455-6431
}

\section{SILVA, Romildo Barros da}

Doutorando do Programa de Pós-Graduação em Linguística e Literatura da UFAL - PPGLL E-mail: romildomi@hotmail.com

ORCID ID: https://orcid.org/0000-0002-3482-2577

\section{RESUMO}

Este artigo analisa as diversas maneiras como cada orador (ethos) se apresenta em lives, em contexto universitário, as quais estão relacionadas ao caráter demonstrado pelo seu ethos, com evidências de prudência, virtude e benevolência. Centra-se na Retórica, a arte de convencer e persuadir o outro pelo discurso, no plano das ideias e das emoções. Esses e outros conceitos aqui discutidos fundamentam-se em Abreu (2009), Aristóteles (2011), Ferreira (2019) e (2015), Marcuschi (2008) e (2003), Meyer (2000) e (1994), Perelman e Olbrechts-Tyteca (2014) entre outros. Segue uma abordagem qualitativa, e sua relevância se dá por trabalhar um corpus diferenciado e por propiciar análises de diferentes manifestações do ethos (orador) na função monologal/ dialogal quando expõe a temática proposta para um auditório universal e, na função dialogal, quando responde às questões provenientes dessa mesma temática, em um espaço previamente combinado, o Youtube, amparado pela difusão das redes sociais. Os resultados apontam para uma tendência de o ethos mostrar-se, inteligentemente, de modo geral, como sábio, poderoso, articulador das ideias e ardiloso, quando em 
situação monologal/dialogal, o que Ihe é propiciado pelos artifícios retóricos como o argumento de autoridade, além de outros. Por outro lado, esse mesmo ethos se mostra flexível, cordato e calmo, ao responder perguntas acerca do tema ora discorrido pelo uso informal da sua linguagem, que se apresenta comumente modalizada, livre e espontânea.

Palavras-chave: Ethos. Logos e Pathos. Estudos retóricos. Oralidade.

\section{ABSTRACT}

This article analyzes the different ways in which each orator (ethos) presents himself in lives transmissions, in a university context, which are related to the character shown by his ethos, with evidence of prudence, virtue and benevolence. It focuses on Rhetoric, the art of convincing and persuading the other through discourse, in terms of ideas and emotions. These and other concepts discussed here are based on Abreu (2009), Aristotle (2011), Ferreira (2019) and (2015), Marcuschi (2008) and (2003), Meyer (2000) and (1994), Perelman and Olbrechts-Tyteca (2014) among others. It follows a qualitative approach, and its relevance is given by working with a different corpus and by providing analyzes of different manifestations of the ethos (orator) in the monologal/dialogical function when it exposes the proposed theme for a universal auditorium and, in the dialogical function, when it responds to issues arising from this same theme, in a previously agreed space, Youtube, supported by the diffusion of social networks. The results point to a tendency for ethos to show itself, intelligently, in general, as wise, powerful, articulator of ideas and cunning, when in a monological/dialogical situation, which is provided by rhetorical devices as the argument of authority, and others. On the other hand, this same ethos shows itself to be flexible, reasonable and calm, when answering questions about the theme now discussed by the informal use of its language, which is usually modalized, free and spontaneous.

Key words: Ethos. Logos and Pathos. Rhetorical studies. Orality.

\section{CONSIDERAÇÕES INICIAIS}

Este artigo tem como objetivo analisar as diversas maneiras como cada orador (ethos) se apresenta durante lives ${ }^{1}$, para apresentação de

1 Entende-se por live uma forma textual verbal e não verbal na comunicação contemporânea com a característica principal de permitir a transmissão ao vivo (SOUZA, 2021). 
alguma temática, com relação diretamente ao seu caráter demonstrado, com possíveis evidências de prudência, virtude e benevolência. Está inserido na Retórica, que é entendida como a arte de convencer e persuadir o outro pelo discurso, no plano das ideias e das emoções, o que poderá conduzir o auditório à execução das intenções do orador.

A discussão da temática teve contribuições de dois grupos de pesquisa, um oriundo da Universidade Estadual de Alagoas, outro da Universidade Federal de Alagoas. O estudo agrega quaisquer estudiosos voltados aos construtos retóricos e conversacionais com aplicação em ações persuasivas por meio de gêneros textuais/discursivos ${ }^{2}$ orais e escritos.

O trabalho se desenvolve dentro de uma concepção de língua(gem) como "uma atividade social, histórica e cognitiva, desenvolvida de acordo com as práticas socioculturais e, como tal, obedece a convenções de uso fundadas em normas socialmente instituídas" (MARCUSCHI, 2008, p. 64), com uma noção de texto, considerada como unidade de sentido, necessitando para isso de uma situação discursiva, de interlocutores, das categorias de espaço e tempo e de um propósito claro e definido $(\mathrm{KOCH}$, 2018). Além disso, elegem-se as noções de práticas da linguagem (lives) (BNCC, 2017) ${ }^{3}$, configuradas nas diversas ações linguísticas que contribuem para o desenvolvimento da competência comunicativa do corpo docente e discente.

Com uma fundamentação centrada nos estudos retóricos com análises de discursos, desde a sua gênese com aspectos ligados à estruturação e elaboração de esquemas, até a sua aplicação interativa nos diversos campos sociais e culturais, este artigo vislumbra analisar, entre outras categorias, as diversas manifestações do orador (ethos) em situações monologal/dialogal e dialogal, quando em intenções de persuadir seu auditório universal ${ }^{4}$. Nesse sentido, toma-se a tríade argumentativa de Aristóteles (2011), com um ethos representado pelo orador do discurso, um pathos (os sentimentos e as emoções despertados pelo ethos) e o próprio objeto teórico constituído pela temática discursiva (logos).

2 Textuais/discursivos - Neste trabalho, as duas formas são usadas indiferentemente, embora se reconheça a discussão acerca disso.

3 Por o trabalho provir de ações desenvolvidas com graduandos de docência, aponta-se a Base Nacional Comum Curricular (BNCC), documento que organiza a sua estrutura em práticas de linguagem, como a leitura, produção de textos, oralidade e análise linguística/semiótica (BNCC, 2017)

4 Auditório Universal - entende-se por esse auditório um conjunto de pessoas que apresentam variáveis que exibem dificuldade em seu controle. "O público que assiste a um programa de televisão configura um auditório universal. São homens e mulheres de todas as classes sociais, de idades diferentes, diferentes profissões, diferentes níveis de instrução e de diferentes regiões do país" (ABREU, 2009, p. 40). 
Com essas pontuações feitas, os seguintes questionamentos foram organizados para a execução do trabalho, com o propósito de nortear o aparato teórico e a sua aplicação nas análises das práticas retóricas após a transcrição de lives: a) Quais as diferentes formas retóricas utilizadas pelo(s) orador (es) em situações monologal/dialogal e dialogal? e b) Quais categorias similares ou não atuam nas duas situações estudadas (monologal e dialogal)? A grande meta neste estudo é responder a essas perguntas, em um diálogo constante entre os aspectos teóricos e sua aplicação em situações comunicativas.

O trabalho centra-se basicamente em dois pontos principais: o primeiro está relacionado à explicação dos aspectos teóricos com base nos elementos constituintes da Retórica, com ênfase nos meios de persuadir o seu auditório; o segundo está vinculado às análises de lives em que caracteres retóricos do ethos são evidenciados para que sejam construídas as maneiras de projeção desse ethos nas situações apresentadas: monologal/dialogal e dialogal. A última seção apresenta uma síntese das discussões, a qual se encontra nas considerações finais.

\section{LIVE: GÊNERO TEXTUAL INTERATIVO}

Em Marcuschi (2008, p. 90), reconhece-se texto como "evento que atualiza sentidos e não como uma entidade que porta sentidos na independência de seus leitores.". Com esse pressuposto, faz-se aceitável entender o conceito de live como um gênero textual que atualiza sentidos ao fazer-se ao vivo pelo produtor com vistas a um leitor virtual. Esse gênero, realmente, demarca a evolução dos meios de comunicação e se torna, em contexto de pandemia, essencial para a interação humana de maneira global.

Souza (2020, p. 2) compreende que live, ao mencionar sua tradução, é uma "transmissão em ondas sonoras via rádio e que hoje é usada para transmissão ao vivo, audiovisual.". Com o advento da internet, esse gênero assume características de suporte textual devido a sua multiplicidade de formatos e sites de difusão, tais como Youtube, Instagram, Google Meet e outros. No entanto, por possuir características específicas, e ainda se situar em diversos suportes como os anteriormente referidos, aceita-se live mais como gênero do que como suporte de textos.

Nesse viés, durante a pandemia causada pelo COVID-19, aceitase que lives são 
apresentações presenciais realizadas por meio de redes sociais virtuais, como o Instagram, Facebook ou YouTube, [além disso] podem ser entendidas e vistas não como um novo gênero que surge, porém como um gênero acadêmico que foi remodelado, ressignificado e passou a fazer parte do cotidiano das pessoas que precisaram adaptar-se às implicações provocadas por um novo tempo, exigidas pelo meio no qual estão inseridas. (FETTERMANN; BENEVENUTI; TAMARIZ, 2020, p. 4)

Além desse aspecto inovador, que é sua ressignificação, o gênero live rompe as barreiras de tempo e espaço, pois, além da interação ao vivo com os internautas, permitem a sua visualização em outro momento, ficando disponíveis para acesso posterior, como relembram Fettermann; Benevenuti; Tamariz (2020). Todas essas transformações nesse gênero compatibilizam com a adaptação que os sujeitos constantemente fazem com a língua no processo interativo, ou seja, lives já existiam, porém foram remodeladas graças a uma necessidade de seus usuários e da própria dinâmica do meio virtual.

Valida-se, portanto, que o gênero live atua como uma prática de linguagem materializada nos meios virtuais e que, além de transmitir instantaneamente informações de um produtor textual, remodela toda a percepção e compreensão de sentidos, uma vez que, ao fazer uma transmissão ao vivo, está submetida às variantes dos gêneros orais e multimodais, podendo ser estudada como gênero da mídia, do meio acadêmico e também profissional.

\section{A RETÓRICA NAS LIVES}

O discurso do orador em lives, constituído em situação de exposição teórica e de respostas a perguntas de um auditório, faz remissão aos estudos retóricos, com ênfase na persuasão, pois esta consiste em um processo simbólico com o qual "os comunicadores procuram convencer outras pessoas a alterar as suas atitudes ou comportamento em relação a um assunto através da transmissão de uma mensagem, num ambiente de liberdade" (PERLOFF, 2003, p. 8). Assim, nesta parte, focam-se algumas definições de Retórica, a tríade argumentativa e a provável eficácia oratória do ethos. 


\section{Retóricas: algumas definições}

Em uma tentativa de definir a Retórica, Platão a define como uma manipulação do auditório. Essa manipulação, diferentemente do que hoje entende-se por esse termo, fazia alusão ao controle efetivo da técnica em si, do discurso, bem como todos os recursos estilísticos e oratórios que deveriam ser aparentados e/ou evidenciados no ato retórico, visando ao auditório. Nesse sentido, a manipulação defendida por Platão, além de ser uma crítica severa aos sofistas da época, uma vez que não visavam à verdade objetiva, indicava também que era necessário ter ética na produção dos discursos persuasivos, além do seu efetivo controle.

Quintiliano, por sua vez, entende a Retórica como a arte de bem falar. O bem falar também repercutia os recursos estilísticos e métodos de conquista da adesão do público, porém o falar bem está associado visivelmente à imagem daquele que fala. Por isso, no entendimento de Quintiliano, as pessoas de bem falam do bem. Por essa razão, o aspecto ético e moral voltou a ser exigência nessa arte/técnica da Grécia antiga.

Aristóteles, precursor da sistematização da retórica, defendia essa técnica como a exposição de argumentos ou de discursos que devem ou visam persuadir. Isso leva, de maneira consequente, à centração nas emoções e paixões despertadas no auditório; ao modo de expressão do orador e aos meios que tornam um discurso persuasivo. Portanto, na sua Retórica, Aristóteles (2011, p. 44) define "a retórica como a faculdade de observar, em cada caso, o que este encerra de próprio para criar a persuasão. Nenhuma outra arte possui tal função". Dessa maneira, abrese caminho para o estudo expansivo dessa técnica que pode ser aplicada não só aos discursos jurídicos, que eram comuns na democracia grega, mas a todo e qualquer discurso público.

A Retórica, portanto, busca a persuasão por meio do discurso. Além disso, para sua verdadeira eficácia, essa arte/técnica grega necessita da articulação das suas categorias de base, a mais conhecida delas é descrita a seguir: os meios de persuasão ou tríade argumentativa.

\section{A tríade argumentativa}

A tríade argumentativa é conjuntamente formada por um ethos ligado à imagem que o retor passa de si no discurso, que é destinado a persuadir um determinado público, não correspondendo precisamente à pessoa do retor; por um pathos, que, para Perelman e Olbrechts-Tyteca (2014, p. 21), por meio dele, "a argumentação visa obter a adesão daqueles a quem se dirige, ela é, por inteiro, relativa ao auditório que 
procura influenciar"; e, por um logos, objeto teórico, que é posto em discussão. Portanto, a arte de argumentar tem, essencialmente, como meta o discurso persuasivo, e a persuasão para ser atingida.

Dessa maneira, entende-se o ethos como "a imagem de si, o caráter, a personalidade, os traços de comportamento" (MEYER, 2007, p. 34). Assim, tudo que é afirmado ou negado em uma discussão pode contribuir para a formação dessa imagem do orador. Afinal, é no e pelo discurso que o ethos é apresentado, constituído e reconfigurado.

O pathos, por seu turno, está associado com "as paixões, as emoções ou simplesmente as opiniões" do auditório (MEYER, 2007, p. 36). Sem esses elementos o próprio discurso não teria meta. Nesse sentido, toda palavra enunciada pelo retor está direcionada para essas pressuposições ou valores que ele cria ou conhece do seu auditório. Assim, o pathos é o que norteia os argumentos do orador e alinha as intencionalidades do ethos.

O logos é a prova racional da retórica. É por meio dela que se expressam o ethos e o pathos dos envolvidos num ato retórico, conforme Meyer (2007). O logos, portanto, é responsável pela expressão dos argumentos. Nas palavras de Reboul (2004), o logos é a argumentação propriamente dita.

Diante desses conceitos, este trabalho aponta para a importância de buscar o entendimento dos recursos persuasivos utilizados pelo orador (ethos) para a produção do sentido, e do reconhecimento dos dispositivos utilizados para envolver/seduzir o auditório (pathos) e tentar convencê-lo de algo. Com o conhecimento de tal dinâmica discursiva, o auditório poderá, de forma consciente, melhor posicionar-se perante aquilo que lhe é proposto.

Ao entender como o orador consegue envolver seu auditório, seja pelo uso dos recursos que o emocionam (ethos e pathos), seja pela maneira como estrutura seus argumentos (logos), o auditório poderá, com esse conhecimento, tornar-se "Iivremente" - no sentido de escolher racionalmente, após sua reflexão e crítica e por isso, livre - a posição frente aquilo proposto pelo orador. Com isso, salienta-se que trabalhar a Retórica com essa proposta significa, conforme propõe Reboul (2004), trabalhar uma leitura retórica dos discursos.

Aristóteles (2011), ao referir-se à tríade argumentativa, menciona três tipos de argumento: Ethos e Pathos (de ordem afetiva) e Logos (de ordem racional), para o que Meyer (1994, p. 43), assim enuncia: "o orador é simbolizado pelo ethos: na sua 'virtude'[...]. O auditório é 
representado pelo pathos: para o convencer é preciso impressioná-lo. [...] Resta, enfim, o terceiro componente, sem dúvida o mais objetivo: o logos, o discurso".

Nesse sentido, para Santos e Rocha (2020), ao tratarem dos meios de persuadir ethos, pathos e logos, a partir da Nova Retórica teorizada por Perelmen e Olbrechts-Tyteca (2014), admitem que essa tríade não deve ser vista de modo separado, mas sim de maneira conjunta, construída, pois se torna impossível a realização de um elemento sem que não tenha havido certamente o envolvimento dos outros. Desse modo, a persuasão que acontece pelo caráter do orador é alcançada quando o discurso é proferido de tal maneira a deixar a impressão de que o orador é digno de fé; o auditório, em consequência, é persuadido quando é conduzido à emoção por meio dos artifícios persuasivos proferidos pelo orador.

\section{Eficácia oratória do ethos}

Com base em Ferreira (2019), para o ethos considerado, no exercício da sua vocalidade intencional sobre um auditório, surgem três fatores que se interligam e se amalgamam, daí resultando a eficácia oratória. Esses elementos são representados, em primeiro lugar, pela constituição oratória da dignidade do orador, a qual envolve a phrónesis (sensatez), a areté (virtude) e a eúnoia (benevolência). Em seguida, aparece o caráter documental e social do ethos, que representa o poder. Nesse sentido, o autor assim explica: "o ethos, visto como reflexo histórico e social da vocalidade, atua no interior do discurso polêmico para impor, pela autonomia e poder institucional, o discurso dominante, aquele que determina valores e molda o viver em sociedade". (FERREIRA, 2019, p. 19).

Ainda fazendo parte da constituição oratória do ethos, aparece a negociação do relacionamento entre orador e auditório, muito bem denominado por saber, uma vez que o orador pode conseguir pelo seu discurso a persuasão do auditório com o uso de palavras de sabedoria expressas quando da explicação das suas ideias e dos seus pensamentos, assim explicado: "o ethos de um orador [...] pode ser medido pela habilidade de atrair o interesse, prolongar a atenção e ativar as paixões do auditório para o estabelecimento do acordo pretendido por meio da demonstração de um saber enciclopédico e de um saber virtual" (FERREIRA, 2019, p. 21).

Para maior eficácia oratória do ethos, é preciso ainda que os seus caracteres já descritos sejam somados a outros saberes que, 
naturalmente, vão sobressair as virtudes ligadas ao estilo e à oratória: as primeiras exemplificadas pela clareza, adequação, ornamentação adequada e pelo decoro; as últimas representadas pela eloquência, competência verbal, segurança e pelo comedimento (FERREIRA, 2019, p. 21). Além disso, considera-se que o ethos é movido por paixões que são "todos aqueles sentimentos que, causando mudança nas pessoas, fazem diferir seus julgamentos" (MEYER, 2000, p. XIV); as paixões não são estados permanentes, pois são apenas provocadas pelo orador com caráter transitório.

\section{ASPECTOS METODÓLOGICOS E ANÁLISES RETÓRICAS}

O trabalho seguiu uma linha qualitativa, conforme Flick (2009) e Bogdan; Biklen (1994), com seleção de lives (eventos gravados ao vivo com transmissão remota, de forma on-line), nível universitário, durante a pandemia, por um espaço de tempo equivalente a um mês de duração, o mês de março do ano dois mil e vinte (03/2020). Assim, procedeu-se à captura de imagens e à transcrição dos dados orais, segundo Marcuschi (2003) e Preti (2000). Foi escolhido para este trabalho o momento de live intitulado Argumentação e Interação em Linguística Textual, exibido em 15/05/2020.

Foram catalogadas 3 (três) lives transmitidas na mesma plataforma (Youtube) durante a realização de um evento on-line da Associação Brasileira de Linguística (ABRALIN). Essas lives são de acesso público e ainda podem ser acessadas no site ${ }^{5}$ ora informado.

A seleção dos fragmentos e da respectiva live considerou a temática abordada pelo palestrante (texto e linguagem), a transformação de situações dialogais e monologais/dialogais, bem como a sua consonância com as categorias retóricas em estudo.

A identidade dos participantes envolvidos na pesquisa foi preservada, uma vez que apenas seus discursos transcritos foram o foco de análise. Além disso, os quatro fragmentos escolhidos para exemplificação da temática mostraram-se suficientes para elucidação das categorias analisadas.

\section{Análise 1 - 0 ethos em uma situação monologal/dialogal ${ }^{6}$}

A análise 1 contempla a exposição teórica feita pelo orador acerca da Linguística Textual, com considerações sobre os constructos 5 Live disponível em: <https://www.youtube.com/watch?v=oBcqw7LXclk>. Acesso em 08 jan. 2021.

6 Situação monologal/dialogal - Registra-se tal nomenclatura porque o orador faz uma exposição teórica individual e embora, assim o seja, sua voz é resultado da confluência de várias vozes, o que se explica, muitas vezes, até por elaborar perguntas retóricas feitas ao auditório universal on-line. 
referentes a "aportes teóricos de outras correntes", na modalidade oral, em uma situação monologal/dialogal. Neste caso, o ethos, pode obter a sua eficácia oratória por apresentar qualidades de sensatez (phrónesis), virtude (areté) e benevolência (eúnoia), além de caracteres ligados ao poder, pois ocupa um lugar instituído socialmente (ocupante de um prestígio acadêmico). Além disso, esse ethos revela saber por ser o portavoz da Linguística Textual na área acadêmica. Eis o texto a seguir:

$\mathrm{X}$ : o tema da nossa mesa é linguística textual a argumentação e interação e:: no nosso resumo eu dizia assim que a linguística textual ajusta a seu escopo de análise outros aportes teóricos de correntes argumentativos' discursivos e interacionais numa interdisciplinaridade focada... e aí... a primeira coisa que que podem me perguntar é" o que são essas articulações teóricas" são são empréstimos teóricos que a linguística textual faz e se apropria deles para ter o seu lugar de fala"... não não são empréstimos teóricos porque é preciso haver muita coerência nessa articulação teórica e eu estou tomando essa interdisciplinaridade focada ou focalizada no sentido Charaudeau para quem as noções propostas por diferentes disciplinas podem ser retomadas por outra desde que redimensionadas no âmbito dos pressupostos desta (...)

Corpus do pesquisador- live 1

Análise 1: 0 ethos numa situação monologal/dialogal

Além do descrito antes, o ethos, na análise 1, para manter o poder instituído, com as atenções do auditório voltadas para si, e, assim, persuadir esse auditório, elabora perguntas retóricas, como em: a) "o que são essas articulações teóricas" e b) "são são empréstimos teóricos que a linguística textual faz e se apropria deles para ter o seu lugar de fala"; talvez o ethos queira ser gentil, mas o desejo é cercear o conhecimento, por realmente ser o portador da exposição do saber. Essas perguntas retóricas são "(...) tendenciosas porque são colocadas para se conseguir determinadas respostas, calculadamente previstas, isto é, tendo o ar de respeitar a liberdade do destinatário, as perguntas retóricas servem para impor-lhe ideias prévias" (NASCIMENTO; OLIVEIRA; BARALDO, 2020, p. 3).

Além disso, o ethos busca o argumento de autoridade, ao dizer: "eu estou tomando essa interdisciplinaridade focada ou focalizada no sentido Charaudeau para quem", pois outro poder reforça mais ainda o poder desse ethos. O argumento de autoridade é, para Ferreira (2015, p. 166), "o prestígio, o caráter, o ethos da pessoa citada é fator crucial para a validação das intenções. Os discursos dos competentes sustentam esse argumento". 
Pode-se pensar em um ethos movido pelo poder e paixão, com porte de uma suposta calma, para impor seus conceitos a fim de persuadir um auditório naturalmente sequioso por conhecimento. Desse modo, tem-se um ethos com atributos ligados à sabedoria (sábio), ao poder (poderoso), à articulação de ideias (articulador), além de um ethos que se apresenta calmo, pois é a calma "uma verdadeira paixão porque reflete, interioriza uma certa imagem que o outro forma de nós, de sorte que, ao mesmo tempo, agimos sobre ele, mantendo (ou encontrando) nossa calma a seu respeito." (MEYER, 2000, p. XLIV).

\title{
Análise 2 - 0 ethos numa situação monologal/dialogal
}

A análise 2 refere-se ao momento quando o orador expunha acerca dos termos-chave da sua temática, quais sejam: "interação, gênero, texto argumentativo" e, para isso, evoca argumentos retóricos bem definidos, pois "implica demonstrar ideias para clarear no espírito do outro nossa posição diante de um assunto polêmico" (FERREIRA, 2015, p. 14). Para isso, o ethos, sequioso por persuadir o auditório, considera a condição humana no tocante aos seus sentimentos, impulsos, às suas paixões, numa fusão de três ordens que correspondem à linha argumentativa (docere), emotiva (movere) e atraente (delectare) (FERREIRA, 2015, p. 16). A análise centra-se no texto a seguir:

\begin{abstract}
então estou focalizando assim os termos chave dessa mesa... interação gênero texto argumentação... a qual chegarei em breve' por influência de Ruth Amossy sustentamos que o sujeito realiza atos negociáveis de persuasão para os quais convoca diversos modos de expressão que podem ser verbais gestuais mímicos icônicos... né' então o locutor é portanto responsável por tais atos e para realizá-los ele desenvolve estratégias de persuasão na tentativa de exercer alguma influência sobre o outro... mas também existe um outro aporte teórico que nós convocamos para dentro da linguística textual' e que nós deixamos como algo pressuposto...... como sem risco de contradição admitir que o sujeito das trocas linguageiras é simultaneamente intencional" estratégico né' e clivado... mas se aceitamos com a semiolinguística que o sujeito do ato de linguagem deve ser visto sempre como uma dupla identidade uma identidade psicossocial no seu estatuto de sujeito Corpus do pesquisador- live 1
\end{abstract}

Análise 2: 0 ethos numa situação monologal /dialogal

Desse modo, o orador, para explicar sua temática, conclama as investigações teóricas que ratificam o poder valorativo das suas afirmações perante o auditório, por meio do argumento de autoridade, ao evocar "Ruth Amossy", quando discorre sobre o sujeito, assim enunciando: 
"o sujeito realiza atos negociáveis de persuasão para os quais convoca diversos modos de expressão que podem ser verbais gestuais mímicos icônicos... né", pois esse argumento "justifica uma afirmação baseandose no valor de seu autor". (REBOUL, 2004, p. 229).

Assim, o orador, ao explicar o que fora enunciado, passa a se deter na figura do locutor, pois dele advém a origem dos atos verbais, gestuais, mímicos e icônicos, cabendo-lhe ainda, quando for usá-los, o desenvolvimento de estratégias persuasivas na tentativa de influenciar seu receptor. A seguir, como ênfase mantenedora da atenção do auditório, o ethos questiona: ".... como sem risco de contradição admitir que o sujeito das trocas linguageiras é simultaneamente intencional" estratégico né' e clivado". Para isso, o ethos sente a necessidade de outro aporte teórico, o que o faz, utilizando-se do argumento de autoridade representado por uma das áreas do conhecimento linguístico, a Semiolinguística ${ }^{7}$, que representa não uma identidade pessoal constituída, mas uma vasta área, em que estão inseridas grandes representações individuais.

Os dois argumentos de autoridade são bastante significativos, pois o primeiro (Ruth Amossy) representa a unidade representante das orientações discursivas; o segundo (Semiolinguística), o todo em que estão inseridos os seguidores dessa área ${ }^{8}$. A escolha do argumento de autoridade pelo ethos significa ratificar os atos ou juízos de uma pessoa ou a inclusão da parte no todo ou vice-versa.

Os argumentos de autoridade utilizados pelos diversos tipos de ethos são cercados pelo da definição, o mais importante dos argumentos, por permitir que esse ethos delineie o assunto com clareza, precisão e comedimento. Assim, aparecem as definições nos fragmentos: "o sujeito das trocas linguageiras é simultaneamente intencional 'estratégico né' e clivado" e "o sujeito do ato de linguagem deve ser visto sempre como uma dupla identidade uma identidade psicossocial no seu estatuto de sujeito".

Em uma situação expositiva de live, o ethos aqui analisado caracteriza-se como senhor do saber (sábio), portando também a phróneses, areté e eúnoia, com caracteres de representante do poder instituído, o que torna o seu discurso persuasivo, pois a suposta calma desse ethos é entendida como um artifício para persuadir o auditório,

7 Semiolinguística - trata-se de uma abordagem psicossociológica, cujo foco é a matéria linguística com atuação em um contexto psicossocial.

8 Inferir as ideias de unidade no argumento de autoridade em Ruth Amossy e de todo em Semiolinguística provieram de Perelman; Olbrechts-Tyteca ([1958] 2014, p. 348), ao afirmarem: "A relação de inclusão ocasiona dois grupos de argumentos que há interesse em distinguir: os que se limitam a demonstrar essa inclusão das partes num todo e os que demonstram a divisão do todo em suas partes. 
pois conduz a estabelecer a simetria entre si (o ethos) e o outro (o auditório), o que gera a possível aceitação dos argumentos por parte desse auditório.

\section{Análise 3 - 0 ethos em uma situação dialogal ${ }^{9}$}

A análise 3 destina-se às informações de um ethos que responde à questão feita por um auditório que escreve as perguntas no chat, que depois são lidas pelo mediador. Para este momento, foi selecionado um dos pares pergunta/resposta a seguir:

X: a Y pergunta... é o gênero que permite a flexibilidade dos modos argumentativos ou sujeito pode transgredir o gênero e realizar essa flexibilização"

$\mathrm{X}$ : acredito que como os gêneros são práticas sociais né... diversificadas e tipificadas a gente precisa atender a: duas forças ao mesmo tempo a certas a certas convenções que são impostas e nós sabemos da existência delas... na... nessa área tecnológica nós sabemos um pouco menos... aliás bem menos... mas a gente tem uma ideia certa ideia de como as práticas discursivas devem se dar... mas mesmo assim as transgressões podem acontecer né... agora se os estereótipos mudam-se todas as relações sociais mudam né"... então... claro que pode haver transgressões sempre haverá também restrições sociais postas a essas práticas Corpus do pesquisador- live 1

\section{Análise 3: 0 ethos em situação dialogal}

Quanto ao questionamento feito, evidencia-se não somente ser pertinente ao assunto tratado, bem como requerer um grau de discernimento lógico do receptor (auditório), pois ao ser enunciado: "é o gênero que permite a flexibilidade dos modos argumentativos ou sujeito pode transgredir o gênero e realizar essa flexibilização", deverá haver um assentimento por parte do orador conduzido ao termo "gênero", ou a "sujeito". Assim, nesta parte, para a resposta à pergunta, o ethos também se constitui em ser benevolente e calmo, além de estar em posição de poder em relação ao auditório e saber o conteúdo transmitido.

Para responder à questão formulada, observa-se uma flexibilização da linguagem pelo uso de "acredito', para depois definir o objeto teórico, em: "os gêneros são práticas sociais né... diversificadas e tipificadas", argumento da definição. E, assim, o orador com uma linguagem informal, conclama o auditório, ao afirmar: "a gente precisa atender a: duas forças ao mesmo tempo a certas a certas convenções que são impostas", em que aparece uma posição do ethos perante seu enunciado, corroborado pelo operador modal "precisar atender".

9 Situação dialogal- Entende-se aqui o momento quando o orador dialoga com seu auditório; no caso deste trabalho, responde às questões por ele perguntadas. 


\section{Análise 4 - 0 ethos em uma situação dialogal}

Na quarta análise (4), aparece um questionamento acerca do sujeito atravessado no sentido de ser responsável pelo seu dizer. A pergunta é bem formulada, estando enquadrada nos limites da temática discutida. A seguir, aparece o segundo par pergunta/resposta.

$\mathrm{X}$ pergunta... podemos dizer que essa faceta do sujeito dono do atravessado por muitas vozes está relacionado à responsabilidade que ele tem sobre seu dizer" Y: sim claro... ele é atravessado por muitas vozes... as vozes do outro que ele se põe ou que até podem existir no futuro e é atravessado por vozes do inconsciente... mas assim... ele ele apenas tem uma ilusão... de que ele é dono desse dizer e eu acho que a gente só pode pensar em intencionalidade quando observar essa faceta da ilusão de ser dono do seu dizer... não sei se respondi. Corpus do pesquisador- live 1

Análise 4: 0 ethos em situação dialogal

O ethos, numa situação espontânea, inicia sua resposta à pergunta, asseverando positivamente ao enunciar: "sim claro...". A seguir, de maneira descontraída, o ethos começa a definir o sujeito, pois "é atravessado por muitas vozes... as vozes do outro que ele se põe ou que até podem existir no futuro e é atravessado por vozes do inconsciente... mas assim... ele ele apenas tem uma ilusão... de que ele é dono desse dizer". O que se observa é que o próprio enunciado emitido pelo ethos aparece modalizado, emprestando ao estilo um modo dócil, gentil, como em "até podem existir no futuro" em que o modalizador poder mostra a posição desse ethos perante o enunciado.

Como se não bastassem os operadores modais apontados, o ethos, já no final da sua resposta, apresenta um marcador de opinião (ROSA, 1992), representado por eu acho, ao enunciar: "e eu acho que a gente só pode pensar em intencionalidade quando observar essa faceta da ilusão de ser dono do seu dizer...". No citado enunciado, eu acho indica certa incerteza do ethos em relação ao enunciado produzido, e pode pensar mostra a permissividade em relação ao efeito de sentido do enunciado. Ao final, o ethos sente-se de maneira tão tranquila, calma que enuncia: "não sei se respondi" em que o operador modal saber, embora indique certeza, flexibiliza a ação enunciada.

\section{Quadro das construções persuasivas}

O quadro a seguir resume o ethos quanto às operações persuasivas e às suas qualificações em situações diferentes: em duas, o ethos está na 
exposição do assunto (monologal/dialogal); em outras duas, o mesmo ethos responde a questionamentos (dialogal).

\begin{tabular}{|c|c|}
\hline AS INTERAÇÕES PERSUASIVAS & $\begin{array}{c}\text { OPERAÇÕES PERSUASIVAS E } \\
\text { QUALIFICAÇÕES }\end{array}$ \\
\hline $\begin{array}{c}\text { Análise 1: } \\
\text { monologal/dialogal }\end{array}$ & $\begin{array}{c}\text { Uso de perguntas retóricas; argumento } \\
\text { de autoridade; } \\
\text { Sábio, poderoso, articulador e suposta } \\
\text { calma; }\end{array}$ \\
\hline Análise 2: & $\begin{array}{c}\text { Argumento de autoridade e da } \\
\text { definição; }\end{array}$ \\
monologal/dialogal & $\begin{array}{c}\text { Sábio, suposta calma, poderoso } \\
\text { Phrónesis, areté e eúnoia; }\end{array}$ \\
\hline Análise 3: & Flexibilização da linguagem; \\
dialogal & Argumento da definição; \\
& Operadores modais: acredito, saber, \\
& dever e poder; \\
& Calmo, tranquilo, espontâneo; \\
\hline Análise 4: & Uso dos operadores modais; \\
dialogal & Dócil, gentil, tranquilo e calmo. \\
\hline
\end{tabular}

Quadro resumo das análises. Dados da pesquisa.

Este quadro representa o que foi exposto na live em questão, porém, se replicado em lives de eventos científicos, poderão provavelmente apresentar características semelhantes, dado que o próprio gênero e o meio de produção possibilitam essas características afins.

Assim, entender a Retórica significa entendê-la como a arte de persuadir pelo discurso e as distinções entre convencer e persuadir, cabendo ao primeiro o convencimento do outro por meio das ideias; ao segundo, a persuasão dos sentimentos. Desse modo, para que o ethos neste trabalho tivesse efeitos retóricos, foi preciso "imprimir ao dizer o seu poder de influência". (FERREIRA, 2019, p. 11).

Nesse contexto, a persuasão assume papel muito importante quando se investigam as ações inteligentes do ethos, não excluindo o pathos e o logos, os quais formam a tríade argumentativa de Aristóteles. É no ethos em que "reside a força de autoridade que se impõe ou não sobre o auditório, pois se liga a um processo de apresentação do orador diante de ouvintes (ou leitores) identificados por características universais ou particulares" (...) (Ibidem, p. 11). 
O quadro apresentado mostra duas situações de atividade do ethos: uma se realizou quando o orador explicou a temática teórica para um auditório universal, acontecendo na emissão das ideias o cruzamento de várias vozes, uma vez que nenhum ethos pratica o monólogo, mas assim o faz de maneira dialogal; outra realmente aconteceu com o ethos em contato com outras vozes ao responder espontaneamente aos seus questionamentos.

Desse modo, o ethos, em situação monologal/dialogal, na análise 1, ao expor a temática proposta, sequioso por persuadir o seu auditório, fez uso dos argumentos de autoridade e das perguntas retóricas. Em igual situação, esse ethos, na análise 2, ainda usou o argumento de autoridade e da definição. Em situação dialogal, houve, na análise 3, o argumento da definição, mas, por outro lado, aparecem os operados modais e, na análise 4, são depreendidos ainda os operadores modais.

Feitas as análises do ethos nas situações apontados, observa-se que esse ethos nas duas situações analisadas apresenta-se constituído pela phrónesis, areté e eúnoia, além de ser representativo de uma instituição a que pertence e do lugar que ocupa na hierarquia institucional (poder), além de representar um saber instituído. O que se observa é que os recursos retóricos utilizados durante a exposição por esse ethos sinalizam suas caraterísticas como sábio, poderoso, calmo e ardiloso; por ocasião das respostas a questionamentos, o ethos se mostra além de calmo, dócil, espontâneo, gentil e tranquilo.

\section{CONSIDERAÇÕES FINAIS}

Este trabalho situou-se nos estudos retóricos, com ênfase na tríade argumentativa de Aristóteles (2011), o ethos, o logos e o pathos. Defende-se a posição de Meyer (1994) que aponta para uma construção no uso dessa tríade, pois, em se utilizando o ethos, necessariamente os outros (pathos e logos) estão presentes no ato comunicativo. De maneira didática, privilegiou-se o ethos como o foco das considerações trabalhadas.

Nesse sentido, o ethos, para que exiba a sua inteligência retórica, é preciso que haja em si phrónesis, a areté e a eúnoia, em sendo sensato, virtuoso e bom; além disso, nesse entendimento retórico, cada ethos ocupa um lugar institucional, sendo, muitas vezes, porta-voz desse lugar social, além do que representa um poder que ocupa um lugar na sociedade, não sendo só social, mas também ser de poder e quem tem saber tem poder. 
O ethos foi investigado com o objetivo de responder a questionamentos que se resumem nas seguintes afirmações: supõe-se que haja diferentes formas retóricas utilizadas pelo(s) orador (es) em situações monologal/dialogal e dialogal e que seria possível analisar as categorias similares ou não, utilizadas pelo orador/oradores nas duas situações mencionadas.

Quanto à primeira inquietação acerca das formas retóricas para uso da persuasão pelo ethos, as análises apontaram que, em situação monologal/dialogal, apareceram os argumentos de autoridade e da definição e as perguntas retóricas, os quais identificam um ethos como representante de uma instituição do saber acadêmico. Infere-se que esses argumentos são artifícios retóricos utilizados pelo ethos para conseguir a adesão do seu auditório em relação à temática, os quais designam ações de poder desse ethos em relação a esse auditório.

Em situação dialogal, quando a linguagem acontece informalmente, a flexibilização se deu por meio dos operadores modais, que têm a propriedade de modalizar as informações transmitidas pelo orador. Esses operadores mudam a ação do ethos sobre o auditório, fazendo com que o tratamento do objeto teórico seja mencionado de forma suave e amena. Apesar da presença dos operadores modais, ainda apareceu o argumento da definição, pois trata-se de um ethos que ocupa uma posição doutoral.

Desse modo, poder-se-ia inferir que, embora, em situação tensa, por ocasião da exposição teórica quando se dirige a um auditório universal e em situação distensa, quando responde às questões do chat, o ethos apresenta uma inteligência retórica, provida também de um suporte social e de uma marcação de poder. Assim, as definições, as perguntas retóricas e o argumento da definição caracterizam o momento tenso desse ethos acadêmico; os operadores modais e o argumento da definição priorizam a escala da descontração.

Como o uso dos argumentos retóricos tem as suas especificidades, infere-se que, no primeiro momento, esses argumentos tornaram a aparência de um ethos sábio, poderoso, articulador e com suposta calma com a intenção de persuadir o auditório. No segundo, os argumentos retóricos apontam para impregnar na linguagem do ethos certa flexibilidade, fluidez, espontaneidade, tornando-o assim dócil, gentil, tranquilo e calmo.

Dessa maneira, foi possível evidenciar a permuta do ethos de acordo com as situações de interação, uma vez que, de acordo com a 
situação dialogal e monogal/dialogal, diferentes comportamentos foram assumidos por aqueles que intentaram persuadir. Assim, o estudo das paixões envolvidas nos atos retóricos dos mais diversos gêneros, como live e tantos outros do meio virtual, promovem eficácia do ethos e, por sua vez, a persuasividade dos discursos.

\section{REFERÊNCIAS}

ABREU, Antônio Soares A arte de argumentar: gerenciando razão e emoção. 13. ed. Cotia - SP: Ateliê Editorial, 2009.

ARISTÓTELES. Retórica. Trad. Edson Bini. São Paulo: Edipro, 2011.

BOGDAN. Robert; BIKLEN. Sari Knopp. Qualitative researche for education. Boston: Ilyn and Bacon, 1982.

BRASIL, Ministério da Educação. Base Nacional Comum Curricular. Brasília, DF: MEC, 2017.

CERVONI, Jean. A enunciação. Trad. L. Garcia dos Santos. São Paulo: Editora Ática, 1989. FERREIRA, Luiz Antonio. Leitura e persuasão: princípios de análise retórica. São Paulo: Contexto, 2015.

FERREIRA, Luiz Antonio. Inteligência retórica e vocalidade: constituição e manutenção do ethos. In: Inteligência retórica: o ethos. FERREIRA, L. A. (org.) São Paulo: Blucher, 2019.

FETTERMANN, Joyce Vieira; BENEVENUTI, Clesiane Bindaco; TAMARIZ, Annabell Del Real. LETRAMENTOS EM PROCESSO: lives como um gênero textual acadêmico a partir da pandemia do covid-19. Anais do Encontro Virtual de Documentação em Software Livre e Congresso Internacional de Linguagem e Tecnologia Online, [S.I.], v. 9, n. 1, nov. 2020. ISSN 2317-0239. Disponível em: <http://www.periodicos.letras.ufmg.br/index. php/anais_linguagem_tecnologia/article/view/17696>. Acesso em: 21 jan. 2021.

FLICK, Uwe. Introdução à pesquisa qualitativa. 3. ed. Porto Alegre: Artmed, 2009.

$\mathrm{KOCH}$, Ingedore Grünfeld Villaça. A inter-ação pela linguagem. 11. ed. São Paulo: Contexto, 2018.

MARCUSCHI, Luiz Antônio Análise da conversação. 5. ed. São Paulo: Editora Ática, 2003.

MARCUSCHI, Luiz Antônio. Produção textual, análise de gêneros e compreensão. São Paulo: Parábola Editorial, 2008.

MEYER, Michel. As grandes paixões segundo Aristóteles. In: A Retórica das Paixões. ARISTÓTELES. Trad. Isis Borges B. da Fonseca. São Paulo: Martins Fontes, 2000. 
MEYER, Michel. A calma, a tranquilidade. In: A Retórica das Paixões. ARISTÓTELES. Trad. Isis Borges B. da Fonseca. São Paulo: Martins Fontes, 2000.

MEYER, Michel. A Retórica. São Paulo: Ática, 1994.

NASCIMENTO, Suzete Silva; OLIVEIRA, Esther Gomes de; BARALDO, Cecília Contani. O uso da interrogação retórica em textos universitário. Disponível em: <http://www. faccar.com.br/eventos/desletras/hist/2007_g/ textos/03.html>. Acesso em: 08 dez. 2020. PERELMAN, Chaïm; OLBRECHTS-TYTECA, Lucie. Tratado de Argumentação: a nova retórica. Trad. Maria Ermantina Galvão G. Pereira. São Paulo: Martins Fontes, 2014.

PERLOFF, Richard. The Dynamics of Persuasion - communication and attitudes in the 21 th century. London and New Jersey: Lawrencen Erlbaum Associates, 2003.

PRETI, Dino. (org.). Fala e escrita em questão. São Paulo: Humanitas, 2000.

REBOUL, Olivier. Introdução à Retórica. Trad. Ivone Castilho Benedetti. São Paulo Martins Fontes, 2004.

ROSA, Margaret de Miranda. Marcadores de atenuação. São Paulo, Contexto, 1992.

SANTOS, Maria Francisca Oliveira; ROCHA, Max Silva da. A Retórica no Rádio Alagoano. Campinas, SP: Pontes Editores, 2020.

SOUZA, Wallas Cabral de. "Live": tipo de gênero textual? Disponível em: <https://www. webartigos.com/artigos/live-tipo-de-genero-textual/166625>. Acesso em: 21 jan. 2021.

RECEBIDO EM: 29/05/2021

ACEITE EM: 09/06/2021 